\title{
Carbon emissions in the life cycle of urban building system in China-A case study of residential buildings
}

\author{
Fang You ${ }^{\mathrm{a}, \mathrm{b}}$, Dan $\mathrm{Hu}^{\mathrm{a}, *}$, Haitao Zhang ${ }^{\mathrm{a}}$, Zhen Guo ${ }^{\mathrm{a}}$, Yanhua Zhao ${ }^{\mathrm{a}}$, Bennan Wang ${ }^{\mathrm{a}}$, Ye Yuan ${ }^{\mathrm{a}, \mathrm{b}}$ \\ a State Key Lab of Urban \& Regional Ecology, Research Center for Eco-Environmental Sciences, Chinese Academy of Sciences, 18 Shuangqing Road, Haidian District, \\ Beijing 100085, China \\ ${ }^{\mathrm{b}}$ Graduate School of Chinese Academy of Sciences, Beijing 100049, China
}

\section{A R T I C L E I N F O}

\section{Article history:}

Received 28 April 2010

Received in revised form 11 January 2011

Accepted 17 February 2011

Available online 13 April 2011

\section{Key words:}

\section{Carbon emissions}

Urban building system

Material and energy flow analysis (MEFA)

Life cycle

Architectural structures

LCCE model

\begin{abstract}
A B S T R A C T
Urban building system assumes significant environmental and ecological implications in terms of a contribution of emissions of $\mathrm{CO}_{2}$ and other greenhouse gases. In order to understand the roles of urban building system in the global and regional climate changes, we set up an integrated model to analyze the carbon emissions of urban building system during its life cycle in this paper, which is called LCCE Model. The further analysis is made to examine the sources of $\mathrm{CO}_{2}$ emissions and the life cycle characteristics of typical architectural structures as masonry-concrete and steel-concrete. We first identified four major sources of $\mathrm{CO}_{2}$ emissions during the whole life cycle of urban building system, which are industrial process emissions, energy consumption emissions, fugitive emissions and land footprint emissions. Given an assumption of a building life cycle of 50 years, we took urban residential buildings as an example and calculated $\mathrm{CO}_{2}$ emissions in the main five phases of an overall life cycle of a residential building system, including constructive materials preparation, building construction and reformation, building operation, building demolition as well as wastes treatment and recycling. A comparison was made to examine the differences of $\mathrm{CO}_{2}$ emissions among buildings with two typical architectural structures as masonry-concrete and steel-concrete. The results show that the latter produces less $\mathrm{CO}_{2}$ emission than the former per unit area. Specifically, the amount of $\mathrm{CO}_{2}$ emission is $329.61 \mathrm{t}$ for masonry-concrete buildings and $315.79 \mathrm{t}$ for steel-concrete buildings per $100 \mathrm{~m}^{2}$. Most emissions come from energy consumption and land footprint, accounting for $78-83 \%$ and $13-20 \%$ of the total emissions respectively.

According to our LCCE model, there is a great potential of reducing carbon emissions in urban building system. The key to reduce carbon emissions during the life cycle of urban buildings is directed to building wastes recycling, improvement of consumption patterns of energy and materials, preferential use of buildings with a moderate floor area ratio and effective utilization of natural energy and ecologically friendly building materials according to the characteristics of local urban development.
\end{abstract}

(c) 2011 Elsevier B.V. All rights reserved.

\section{Introduction}

The global climate system is being affected by the emissions of greenhouse gases from human development, especially urbanization activities, of which the most significant is carbon dioxide $\left(\mathrm{CO}_{2}\right)$ (Prato, 2008). Many countries have set long-term goals for $\mathrm{CO}_{2}$ emission reduction (IPCC, 2007). It is widely accepted that human settlements occupy a small proportion of landmass, while playing a significant role in the change of global carbon cycle (Potere and Schneider, 2007). Accurate analysis of urban carbon cycle and its interactions with other global or regional ecosystems is going to be crucial for predictions of future trajectories of atmospheric $\mathrm{CO}_{2}$

\footnotetext{
* Corresponding author. Tel.: +86 1062849199.

E-mail address: hudan@rcees.ac.cn (D. Hu).
}

concentrations and global climate change. Recent studies have focused on the carbon fluxes of different land type, such as forest (Churkina et al., 2003), grassland (Torssell et al., 2007) and cropland (West and Marland, 2002; Chakraborty et al., 2006), while neglecting carbon fluxes of urban areas or urbanization regions. As one of the main artificial constructions, urban buildings consume various natural resources, including energy, minerals and water, and release many kinds of pollutants or wastes back to the global/regional ecosystems. These inputs and outputs of mass and energy as a kind of metabolism result in global change presented by air pollution and huge amount of carbon emissions. According to data from the Worldwatch Institute, building sector annually consumes $40 \%$ of the stone, sand and gravel, $25 \%$ of the timber (Arena and Rosa, 2003). In the member nations of the European Union, buildings consume approximately $50 \%$ of the total energy use and contribute almost $50 \%$ of the $\mathrm{CO}_{2}$ emissions released to the 
atmosphere through their life cycles (Dimoudi and Tompa, 2008; Pataki et al., 2009). Besides, compared to other sectors, there is the greatest potential of $\mathrm{CO}_{2}$ emission reduction in the construction sector at a relative low expense, reaching 5.3-6.7 $\mathrm{Gt} \mathrm{CO}_{2}$ per year (IPCC, 2007), which makes the studies on $\mathrm{CO}_{2}$ emission reduction from buildings be a hotspot for scientists, publics and policy makers. Although numerous studies have examined several individual phases of a life cycle of buildings, relatively few studies were focused on the carbon emissions over the entire life cycle of buildings. In particular, most studies paid a special attention to energy saving (Buchanan and Levine, 1999; Gustavsson and Sathre, 2006; Dodoo et al., 2009; Li and Colombier, 2009; Kneifel, 2010). Some studies being explicitly dedicated to constructive materials have been done during the recent several years (Seppälä et al., 2002; Nebel et al., 2006), while also neglecting the environmental or ecological performances of the entire building life cycle. The aim of this study is to set up an integrated model (LCCE model) to analyze $\mathrm{CO}_{2}$ emissions over the life cycle of urban building system with two typical architectural structures as masonry-concrete and steel-concrete. The model is intended to serve as an assessment tool to help us identify major sources, fluxes and sinks of carbon cycle in urban building system or urbanizing areas and to improve the building planning, construction and management, finally promote sustainable transition of developmental pattern of urban building system towards a low-carbon one.

\section{Methodology}

\subsection{LCA-based analyzing method for urban building system}

The Life Cycle Assessment (LCA) methodology today represents the main tool used to estimate the positive or negative impacts on various environmental changes and alterations of ecosystems associated to urban building system. Usually, the LCA analysis is presented in the form of aggregation of environmental loads or impacts per unit of building activities, without considering their distributions in time and space (Tukker, 2000). Nowadays, the effective role of LCA methodology in the quantitative assessment of $\mathrm{CO}_{2}$ emissions and its environmental and ecological impacts has also been recognized by relevant international organizations and researchers.

Carbon fluxes related to a life cycle of buildings can be estimated by using concepts and models developed in urban ecology. The concepts of urban metabolism (Wolman, 1965) and material flow analysis (MFA) or material and energy flow analysis (MEFA) methodology are introduced into this research to examine dynamic characteristics of $\mathrm{CO}_{2}$ emissions of urban building system (Ulgiati and Brown, 1998; Warren-Rhodes and Koenig, 2001; Huang and Hsu, 2003). Based on these concepts and methodologies, we especially emphasize the three aspects of an overall process of carbon cycle of urban building system, which are sources, fluxes and sinks.

\subsection{The definition of a building life cycle}

In this article, we define a life cycle of 50 years for urban buildings in accordance with the prevailing design specifications in China, regardless of what the actual life span of a specific building is. From a perspective of building life cycle, the research period spans from the extraction of raw materials needed by buildings to their final demolition when all kinds of wastes are treated or recycled. There are generally five temporal phases including constructive materials preparation, building construction and reformation, building operation, building demolition as well as wastes treatment and recycling. All these phases have to be considered in order to analyze the $\mathrm{CO}_{2}$ emissions and environmental and ecological impacts in the life cycle of buildings.

\subsection{Determination of main sources of $\mathrm{CO}_{2}$ emissions}

We consider four main sources of $\mathrm{CO}_{2}$ emissions based on the guidance of IPCC report (IPCC, 2006): industrial process (extracting of raw materials and processing) emissions, energy consumption emissions, fugitive emissions and land footprint emissions.

\subsubsection{Industrial process emissions (IE)}

Industrial process emissions are caused by chemical reaction inherent to the production processes. For example, cement is made with limestone which releases $\mathrm{CO}_{2}$ during its chemical decomposition. Its calculation is required to convert from material use amount to $\mathrm{CO}_{2}$ emissions amount mainly based on chemical reaction equations.

\subsubsection{Energy consumption emissions (EE)}

This source includes the primary energy consumption and electricity consumption during the life cycle of a building. Primary energy consumption involves a relatively basic transformation from energy use to $\mathrm{CO}_{2}$ emissions. Use of electricity is required to convert used megawatt hours into $\mathrm{CO}_{2}$ emissions according to the parameters of $\mathrm{CO}_{2}$ emissions associated with electricity production composition and efficiency of energy transformation.

\subsubsection{Fugitive emissions (FE)}

Biodegradable organic matter creates $\mathrm{CO}_{2}$ emissions through respiration or combustion. Most of timber wastes in dumps are treated by combustion in China, which also contributes to the total amount of $\mathrm{CO}_{2}$ emissions.

\subsubsection{Land footprint emissions (LE)}

Land footprint means natural land of ecosystems such as vegetational land or wetland occupied by and changed into other non-vegetational types of land use because of human activities. In this research, buildings and relevant wastes appropriate land which is originally vegetational areas or wetlands. $\mathrm{CO}_{2}$ emissions from this source are a representative of change in types of land use from green land to built-up areas.

\subsection{Connecting processes (fluxes) of building life cycle to their $\mathrm{CO}_{2}$ emissions}

From an ecosystem point of view, building processes like a kind of life metabolism can be demonstrated with fluxes of exchanges of materials and energy between building system and its surroundings. We present a conceptual model for the metabolism dynamics of a building system including three components, namely, inputs of constructive materials or energy, transformation and accumulation as a stock of construction materials or energy within the system and outputs of constructive wastes, all of which form a complete dynamic flux process of a building system in the five stages of its life cycle. Obviously, there is a close coupling relationship between building metabolism and $\mathrm{CO}_{2}$ emissions, and a process-based analysis framework representing the relationships between materials and energy fluxes and their carbon emissions sources during the building's life cycle is indicated in Fig. 1.

\subsubsection{Constructive materials preparation}

The main feature of this phase is the intensive inputs of materials and energy. There are mainly six kinds of constructive materials used in a building system, which are cement, steel, timber, brick, gravel and sand. The $\mathrm{CO}_{2}$ emissions mainly come from industrial process emissions and energy consumption 


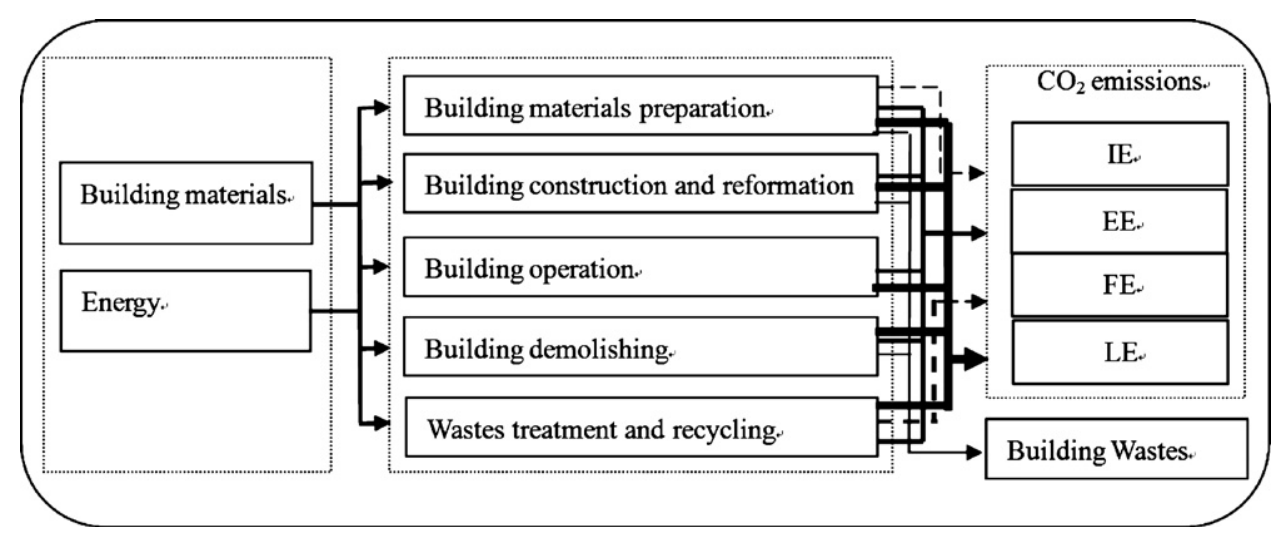

Fig. 1. Conceptual couplings between a building life cycle and $\mathrm{CO}_{2}$ emissions.

emissions. The former refers to emissions coming from production of cement and steel, and so on, resulting from the decomposition of limestone or dolomite, and the latter means the emissions from the consumption of primary energy and electricity during the life cycle of all materials, including the process of raw materials extracting, transportation and production. The $\mathrm{CO}_{2}$ emissions from land footprint occupied by factories and from wastes during processing were not included in this analysis because of data un-availability.

\subsubsection{Building construction and reformation}

In this phase, diverse materials are assembled into a complete building. Huge amount of constructive materials and energy are consumed in a short time to have a building constructed or reformed. On one hand, some construction wastes are generated in this process, which result in $\mathrm{CO}_{2}$ emissions from wastes transportation to landfill. On the other hand, energy consumed in the process of constructive materials transportation, working lighting and building base, wall body and roof accounts for a large amount of $\mathrm{CO}_{2}$ emissions.

\subsubsection{Building operation}

Generally speaking, the intensity of materials inputs and outputs are relative low in this phase. However, buildings last tens of years, also consuming huge amount of energy during their life cycle. In this phase, the consumption of food and other materials by residents is not taken into consideration in our study, and $\mathrm{CO}_{2}$ emissions mainly come from energy consumption.

\subsubsection{Building demolition}

When buildings become out of use, manual or mechanical equipments are used for building demolition. Some wastes from demolition are recycled, while most of building wastes are transported to landfill. Therefore, $\mathrm{CO}_{2}$ emissions mainly come from energy consumption during this period.

\subsubsection{Wastes treatment and recycling}

Most of building wastes are piled up in landfills. Some of them are biodegradable, which create $\mathrm{CO}_{2}$ from fugitive emissions. Other non-degradable wastes occupy land for at least 10 years, which results in land footprint emissions. When taking the recycling of wastes into consideration, most of building wastes are not re-used in a building system, which means that the reduction of $\mathrm{CO}_{2}$ emissions by recycling is relatively limited. The $\mathrm{CO}_{2}$ emissions in this phase are determined by energy consumption, fugitive emissions of building wastes, land footprint emissions and the carbon abatement by wastes recycling.

\section{Life cycle model of carbon emissions for urban building system (LCCE model)}

3.1. Composition and structure of $\mathrm{CO}_{2}$ emissions model for urban building system

Based on the analysis above, $\mathrm{CO}_{2}$ emissions during the life cycle of urban buildings can be quantified by the formulas as follows:

$\mathrm{TE}=\sum_{i=1}^{5}\left(\mathrm{IE}_{i}+\mathrm{EE}_{i}+\mathrm{FE}_{i}+\mathrm{LE}_{i}\right)$

where TE is total amount of $\mathrm{CO}_{2}$ emissions, and $i$ is the $i$ th phase of urban building life cycle, and $i$ is from 1 to 5 . We defined this basic model of analysis as the life cycle model of carbon emissions for urban building system, which was abbreviated to LCCE Model.

$\mathrm{IE}_{i}=\sum_{j=1}^{n}\left(M_{i j} \times F_{j}\right)$

where $I E_{i}$ is $\mathrm{CO}_{2}$ emissions from industrial processes during the phase $i, j$ is the $j$ th type of constructive materials that may produce $\mathrm{CO}_{2}$ emissions, $M_{i j}$ is the use amount of the $j$ th type of building materials during the phase $i$, and $F_{j}$ is the conversion factor of $\mathrm{CO}_{2}$ emissions for the $j$ th type of building materials.

$\mathrm{EE}_{i}=\sum_{k=1}^{n}\left(M_{i k} \times F_{k}\right)$

where $\mathrm{EE}_{i}$ is $\mathrm{CO}_{2}$ emissions from energy consumption during the phase $i, k$ is energy type, $M_{i k}$ is the use amount of the $k$ th type of energy during the phase $i$, and $F_{k}$ is the conversion factor of $\mathrm{CO}_{2}$ emissions for the $k$ th type of energy.

$\mathrm{FE}_{i}=\sum_{l=1}^{n}\left(M_{i l} \times F_{l}\right)$

where $\mathrm{FE}_{i}$ is fugitive emissions during the phase $i, l$ is the $l$ th type of building wastes that are biodegradable, $M_{i l}$ is the generating amount of the lth type of building wastes during the phase $i, F_{l}$ is the conversion factor of $\mathrm{CO}_{2}$ emissions for the $l$ th type of building wastes.

$\mathrm{LE}_{i}=\sum_{m=1}^{n}\left(A_{i m} \times T \times F_{m}\right)$

where $\mathrm{LE}_{i}$ is land footprint emissions during the phase $i, m$ is the $m$ th type of buildings and their wastes, $A_{i m}$ is the area that is appropriated by the $m$ th type of buildings and their wastes during 
the phase $i$, and $T$ is the period of appropriation, $F_{m}$ is the conversion factor of $\mathrm{CO}_{2}$ emissions for vegetational land.

\subsection{Conversion factors}

\subsubsection{Conversion factors for industrial process emissions $\left(F_{j}\right)$}

Among the six main constructive materials of cement, steel, brick, timber, gravel and sand, the cement and steel produce $\mathrm{CO}_{2}$ during the process of production. $\mathrm{CO}_{2}$ is released during the production of cement due to the calcination reaction. Based on the related data on procedural techniques of constructive materials (Josa et al., 2004; Chen et al., 2007), for producing $1 \mathrm{t}$ of cement, there is $0.75 \mathrm{t}$ of clinker, which needs $0.9 \mathrm{t}$ of limestone $\left(\mathrm{CaCO}_{3}\right)$, discharging $0.396 \mathrm{t}$ of $\mathrm{CO}_{2}$. Therefore, the conversion factor for cement is $0.396 \mathrm{t} / \mathrm{t}$. For steel, $1 \mathrm{t}$ of steel requires $0.367 \mathrm{t}$ of limestone $\left(\mathrm{CaCO}_{3}\right)$ and $0.328 \mathrm{t}$ of dolomite $\left(\mathrm{CaMg}\left(\mathrm{CO}_{3}\right)_{2}\right)$, which discharges 0.319 t of $\mathrm{CO}_{2}$ (Gielen and Moriguchi, 2002). In this way, the conversion factor for steel is $0.319 \mathrm{t} / \mathrm{t}$.

\subsubsection{Conversion factors for energy consumption emissions $\left(F_{k}\right)$}

Coal, Oil and natural gas are mostly used primary energy. The conversion factors of $\mathrm{CO}_{2}$ emissions vary with types, quality and combusting conditions of energy. To be simplified, the conversion factors of primary energy for $\mathrm{CO}_{2}$ emissions in this research are taken from the 2006 IPCC Guidelines for National Greenhouse Gas Inventories (IPCC, 2006), as shown in Table 1.

Electricity is a type of secondary energy, being generated in power plants through energy conversion from primary energy. The $\mathrm{CO}_{2}$ emissions factor is affected by the procedure and efficiency of electricity generation. In this study we use the conversion efficiency of 0.38 for thermal power based on the China Energy Statistical Yearbook (NBS, 2009a) and the composition of primary energy for electricity generation is shown in Table 2. According to the percentages of fossil energy and their conversion efficiency from heat energy into electricity, the $\mathrm{CO}_{2}$ emissions factor for electricity is calculated to be about $0.798 \mathrm{~kg} / \mathrm{kwh}$.

\subsubsection{Conversion factors for fugitive emissions $\left(F_{l}\right)$}

Among the six kinds of constructive materials, except timber, most of them are non-degradable, such as cement, steel, sand, gravel and brick. When transported to landfills, timber may release $\mathrm{CO}_{2}$ by respiration or combustion. The fugitive emissions factor for timber is about $1.467 \mathrm{t} / \mathrm{t}$ (IPCC, 2006).

\subsubsection{Conversion factors for land footprint emissions $\left(F_{m}\right)$}

Land footprint is caused by both buildings and their wastes. The land footprint is the summed area of the area occupied by buildings, infrastructures and the area required by wastes treatment. The former is land area occupied by building itself and relevant infrastructures, and the latter is determined by the total amount of wastes and required land area for treating a unit of

\section{Table 1}

Emission factors for primary energy.

\begin{tabular}{lll}
\hline Energy type & $\mathrm{CO}_{2}$ emissions factors & Unit \\
\hline Coal $^{\text {eq }}$ & 2.46 & $\mathrm{~kg} / \mathrm{kg}$ \\
Oil & 2.76 & $\mathrm{~kg} / \mathrm{l}$ \\
Natural gas & 2.09 & $\mathrm{~kg} / \mathrm{m}^{3}$ \\
\hline
\end{tabular}

Note: a unit of Coal ${ }^{\text {eq }}$ is equal to $2.926 \times 10^{7} \mathrm{~J}$.

Table 2

Composition of primary energy for electricity power production in 2008 in China.

\begin{tabular}{llllll}
\hline Energy type & Coal & Oil & Natural gas & Water & Nuclear \\
\hline Percentage (\%) & 80.87 & 11.93 & 4.13 & 2.73 & 0.34 \\
\hline
\end{tabular}

wastes, which is about $0.067 \mathrm{~m}^{2} / \mathrm{t}(\mathrm{Li}, 2009)$. In this study, we assume that the land occupied by buildings, infrastructures and their wastes is originally vegetational one, which generates as much as $73.66 \mathrm{~kg} /\left(\mathrm{a} \mathrm{m}^{2}\right)$ of $\mathrm{CO}_{2}$ (Chen and $\mathrm{Su}, 1998$ ).

\section{A case study of residential buildings}

\subsection{Estimation of material flows of residential building system}

\subsubsection{Site investigations and data collection}

Urban residential buildings consist of different architectural structures which are made of various types of constructive materials. This analysis takes into account of six main constructive materials of cement, steel, brick, timber, gravel, sand and two types of dominate architectural structures of masonry-concrete and steel-concrete for survey. We investigated about 46 buildings in China, and the main items of building survey include their name, age, storey, architectural structure and area. For these sampling buildings, we obtained the necessary data on uses of constructive materials, land use and bill of quantities for building projects.

\subsubsection{Estimation of material use per unit area of the investigated residential buildings}

According to the survey data of sample buildings, we calculated the total amount of constructive materials used in different types of buildings, then calculated the use amounts of six main constructive materials per unit area, which mainly included materials used only by the main body of buildings (such as walls, foundation or substructure, roof, etc.). We also calculated the average use amount per unit area for each type of buildings of two typical architectural structures (see Table 3). Furthermore, we made an independent sample $T$-test between the two types of building structures, which indicated that the use amounts of cement, steel, brick gravel, timber and sand had significant differences between the two types of architectural structures (Hu et al., 2010).

\subsubsection{Estimation of construction wastes per unit area for the investigated buildings}

The amount of wastes generated is different in different periods of a building life cycle, mainly coming from the phases of materials preparation, building construction and reformation, and demolition. Construction wastes can be quantified by multiplying the quantity of constructive materials with their respective wastage

Table 3

Material use amount of residential buildings per unit area for different architectural structures (unit: $\mathrm{t} / 100 \mathrm{~m}^{2}$ )

\begin{tabular}{lcc}
\hline Constructive materials & \multicolumn{2}{l}{ Architectural structure } \\
\cline { 2 - 3 } & Masonry-concrete & Steel-concrete \\
\hline Cement & $14.9 \pm 0.1$ & $24.6 \pm 2.3$ \\
Steel & $2.5 \pm 0.4$ & $5.9 \pm 0.7$ \\
Timber & $0.7 \pm 0.1$ & $0.8 \pm 0.1$ \\
Brick & $37.5 \pm 8.7$ & $8.2 \pm 3.4$ \\
Gravel & $36.9 \pm 3.5$ & $60.7 \pm 5.5$ \\
Sand & $44.5 \pm 3.2$ & $41.7 \pm 2.9$ \\
Total & $136.9 \pm 16.8$ & $141.9 \pm 14.8$ \\
\hline
\end{tabular}

Source: Hu et al. (2010).

Table 4

Wastage rates and recycling rates for different kinds of constructive materials.

\begin{tabular}{lcccccc}
\hline & Cement & Steel & Timber & Brick & Gravel & Sand \\
\hline Wastage rate (\%) & 3 & 5 & 5 & 3 & 3 & 3 \\
Recycling rate (\%) & 10 & 90 & 20 & 50 & 60 & 60 \\
\hline
\end{tabular}


Table 5

The generation of building wastes for typical architectural structures (unit: $t / 100 \mathrm{~m}^{2}$ ).

\begin{tabular}{|c|c|c|c|c|c|c|c|c|}
\hline \multirow[t]{3}{*}{ Constructive materials } & \multicolumn{8}{|c|}{ Architectural Structure } \\
\hline & \multicolumn{4}{|c|}{ Masonry-concrete } & \multicolumn{4}{|c|}{ Steel-concrete } \\
\hline & UA & $\mathrm{CW}$ & RA & DW & UA & $\mathrm{CW}$ & $\mathrm{RA}$ & DW \\
\hline Cement & 14.9 & 0.44 & 1.45 & 13.01 & 24.6 & 0.74 & 2.39 & 21.47 \\
\hline Steel & 2.5 & 0.12 & 2.14 & 0.24 & 5.9 & 0.30 & 5.04 & 0.56 \\
\hline Timber & 0.7 & 0.03 & 0.13 & 0.54 & 0.8 & 0.04 & 0.15 & 0.61 \\
\hline Brick & 37.5 & 1.12 & 18.19 & 18.19 & 8.2 & 0.25 & 3.98 & 3.97 \\
\hline Gravel & 36.9 & 1.11 & 21.47 & 14.32 & 60.7 & 1.82 & 35.33 & 23.55 \\
\hline Sand & 44.5 & 1.33 & 25.90 & 17.27 & 41.7 & 1.25 & 24.27 & 16.18 \\
\hline Total & 136.9 & 4.15 & 69.28 & 63.47 & 141.9 & 4.40 & 71.16 & 66.34 \\
\hline
\end{tabular}

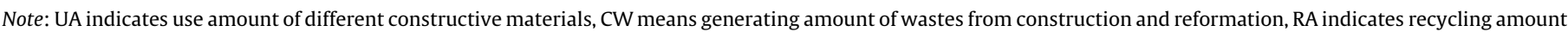
of constructive wastes, DW means wastes from demolishing.

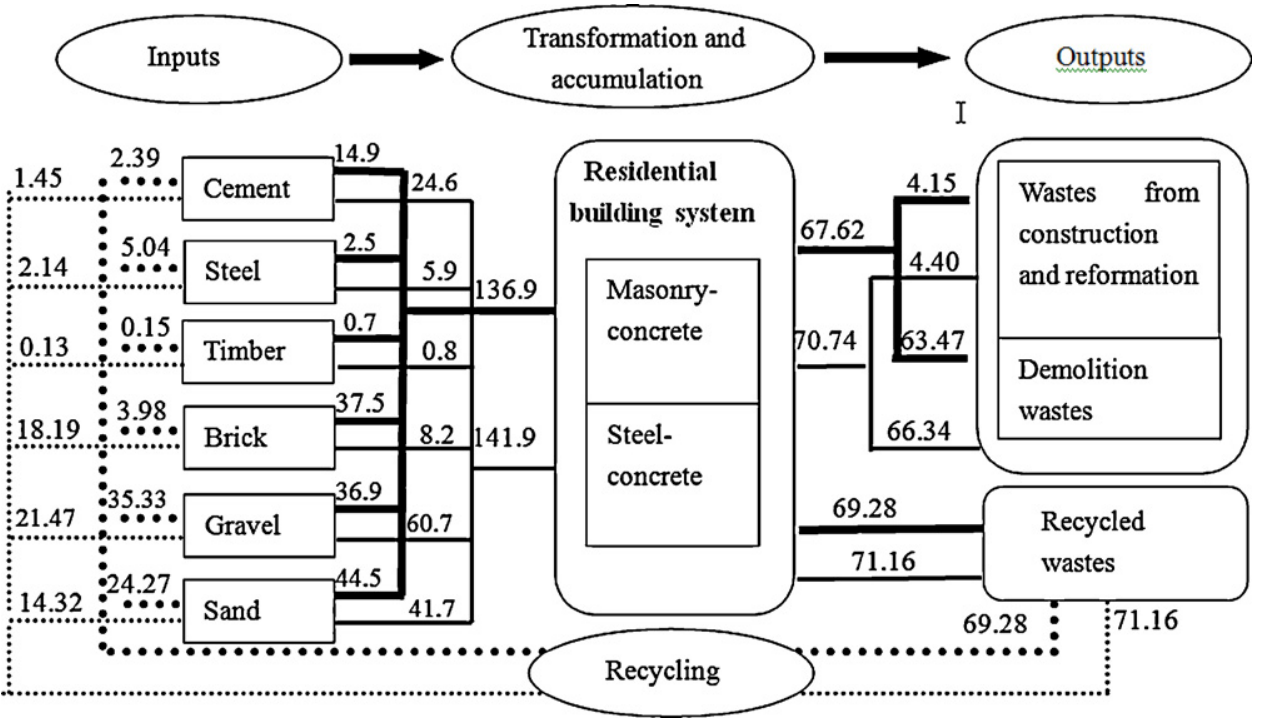

Fig. 2. Material flow chart of residential buildings for typical architectural structures (unit: $\mathrm{t} / 100 \mathrm{~m}^{2}$ ).

rates (Zhang et al., 2006). As for demolition wastes, the re-use and recycling of materials should be excluded (Ma, 2004) (see Tables 4 and 5).

\subsubsection{Material flows of residential building system}

According to the results of analysis above, we established a building material flow chart. This flow chart described a complete dynamic material process of residential building system (Fig. 2.)

\subsection{Estimation of energy flows of residential building system}

\subsubsection{Energy use in the phase of building materials preparation}

Based on the data of energy consumption in relevant researches conducted in China and Europe (Josa et al., 2004; Chen et al., 2007; Gielen and Moriguchi, 2002; SFB, 2005; Koroneos and Dompros, 2007; Schuurmans et al., 2005), we got the energy use of different constructive materials (see Table 6). Then, the total energy use for $100 \mathrm{~m}^{2}$ of residential buildings during this phase is shown in Table 7.

\subsubsection{Energy use in the phase of buildings construction}

The construction of buildings includes the transportation of constructive materials and the electricity amount required for

Table 6

Energy use of per unit constructive materials.

\begin{tabular}{lllllcc}
\hline & Cement & Steel & Timber & Brick & Grave & Sand \\
\hline Coal $^{\text {eq }}(\mathrm{kg} / \mathrm{t})$ & 119 & 490 & 49 & 28 & 1 & 1 \\
Electricity $(\mathrm{kwh} / \mathrm{t})$ & 140 & 144 & 71 & 12 & 50 & 50 \\
\hline
\end{tabular}

driving electronic instruments and lighting, as well as the diesel fuels used by heavy mechanical equipments at the construction sites.

According to the data of China Statistical Yearbook (NBS, $2009 \mathrm{~b}), 60 \%$ of raw materials are transported by railways and $40 \%$ by roads in 2008 , which cost $0.56 \mathrm{~kg}_{\text {coal }}{ }^{\mathrm{eq}} / \mathrm{t}$ and $9.125 \mathrm{~kg} \mathrm{coal}^{\mathrm{eq}} / \mathrm{t}$ per $100 \mathrm{~km}$ respectively. The transportation distances for different constructive materials are listed in Tables 8 and 9.

The energy used in different procedures of construction varied from each other (Peng, 2002). In this study, energy uses for constructing a masonry-concrete building with 6 floors and a steelconcrete building with 10 floors were calculated as examples, see Tables 10 and 11 .

\subsubsection{Energy use in the phase of buildings operation}

Contemporary typical buildings consume most of energy of their life cycles during the operation phase. The use of buildings covers all living activities that include all the energy consumed for heating, cooling, hot water preparation, lighting, cooking and equipment operation. Based on the report of Chinese Ministry of Housing and Urban-Rural Development, energy use for building operation in 2008 (Ding et al., 2009) is shown in Table 12 .

\subsubsection{Energy use in the phase of buildings demolition}

As discussed in the Section 4.2.2, energy used in different procedures varied from each other. As shown in Table 13, we can get the use amount of energy in the phase of demolition and bill of quantities for building projects. 
Table 7

Energy use of constructive materials for per $100 \mathrm{~m}^{2}$ of buildings.

\begin{tabular}{|c|c|c|c|c|c|c|}
\hline \multirow[t]{3}{*}{ Constructive materials } & \multicolumn{6}{|c|}{ Architectural structure } \\
\hline & \multicolumn{3}{|c|}{ Masonry-concrete } & \multicolumn{3}{|c|}{ Steel-concrete } \\
\hline & $\mathrm{UA}(\mathrm{t})$ & $\mathrm{FF}\left(\mathrm{t}\right.$ coal $\left.^{\mathrm{eq}}\right)$ & Electricity (kwh) & $\mathrm{UA}(\mathrm{t})$ & $\mathrm{FF}\left(\mathrm{t}_{\text {coal }}{ }^{\mathrm{eq}}\right)$ & Electricity (kwh) \\
\hline Cement & 14.9 & 1.77 & 2086 & 24.6 & 2.93 & 3444 \\
\hline Steel & 2.5 & 1.23 & 360 & 5.9 & 2.89 & 850 \\
\hline Timber & 0.7 & 0.03 & 50 & 0.8 & 0.04 & 57 \\
\hline Brick & 37.5 & 1.05 & 450 & 8.2 & 0.23 & 98 \\
\hline Gravel & 36.9 & 0.04 & 1845 & 60.7 & 0.06 & 3035 \\
\hline Sand & 44.5 & 0.04 & 2225 & 41.7 & 0.04 & 2085 \\
\hline Total & 136.9 & 4.16 & 7016 & 141.9 & 6.19 & 9569 \\
\hline
\end{tabular}

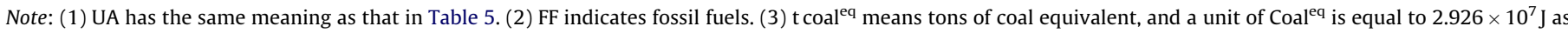
shown in Table 1.

Table 8

Average transportation distances of constructive materials (unit: km).

\begin{tabular}{|c|c|c|c|c|c|c|}
\hline & Cement & Steel & Timber & Brick & Gravel & Sand \\
\hline Distance (by rail) & 446 & 1146 & 1409 & 458 & 458 & 458 \\
\hline Distance (by road) & 171 & 171 & 171 & 171 & 171 & 171 \\
\hline
\end{tabular}

Table 9

Energy use for transportation of constructive materials (Unit: $\mathrm{kg} \mathrm{Coal}^{\mathrm{eq}}$ ).

\begin{tabular}{|c|c|c|c|c|c|c|c|c|}
\hline \multirow[t]{3}{*}{ Building materials } & \multicolumn{8}{|c|}{ Architectural structure } \\
\hline & \multicolumn{4}{|c|}{ Masonry-concrete } & \multicolumn{4}{|c|}{ Steel-concrete } \\
\hline & UA & By train $(\mathrm{kg})$ & By road (kg) & Total (kg) & UA & By train $(\mathrm{kg})$ & By road (kg) & Total $(\mathrm{kg})$ \\
\hline Cement & 14.9 & 22 & 93 & 115 & 24.6 & 37 & 154 & 191 \\
\hline Steel & 2.5 & 10 & 16 & 26 & 5.9 & 23 & 37 & 60 \\
\hline Timber & 0.7 & 3 & 4 & 7 & 0.8 & 4 & 5 & 9 \\
\hline Brick & 37.5 & 58 & 234 & 292 & 8.2 & 13 & 51 & 64 \\
\hline Gravel & 36.9 & 57 & 230 & 287 & 60.7 & 93 & 379 & 472 \\
\hline Sand & 44.5 & 68 & 278 & 346 & 41.7 & 64 & 260 & 324 \\
\hline Total & & 218 & 855 & 1073 & & 234 & 886 & 1120 \\
\hline
\end{tabular}

Note: UA has the same meaning as that in Table 5.

Table 10

Average energy use for different construction procedures.

\begin{tabular}{lll}
\hline Procedures & Energy type \\
\cline { 2 - 3 } & Fuels $(\mathrm{l})$ & Electricity $(\mathrm{kwh})$ \\
\hline Field concrete $(\mathrm{t})$ & - & 44 \\
Premixed concrete $(\mathrm{t})$ & - & 25 \\
Excavation work $\left(\mathrm{m}^{3}\right)$ & 3 & - \\
Land leveling $\left(\mathrm{m}^{2}\right)$ & 0.2 & - \\
Fragmentation $\left(\mathrm{m}^{2}\right)$ & 0.78 & - \\
Lifting $(\mathrm{t})$ & 0.28 & - \\
Lighting $\left(\mathrm{m}^{2}\right)$ & - & 26 \\
\hline
\end{tabular}

Note: "l" denotes a unit of volume "liter", "kwh" indicates "kilowatt-hour".
After demolition, most constructive wastes are transported to landfills by garbage trucks. The distance for transportation of wastes is averagely $20 \mathrm{~km}$ ( $\mathrm{Li}, 2009$ ). According to the parameter above, we can get the use amount of energy in this phase, see Table 14.

\subsubsection{Energy use in the phase of wastes treatment and recycling}

Recycling can decrease landfills and partially compensate for the energy consumption of construction. As recycled products can be substituted for a part of raw materials, on the other hand, they are also responsible for the environmental and ecological impacts related to re-processing and transportation. Generally speaking, when recycled, building wastes can be substituted for the raw

Table 11

Average energy use for per $100 \mathrm{~m}^{2}$ of constructed buildings.

\begin{tabular}{|c|c|c|c|c|c|c|}
\hline \multirow[t]{3}{*}{ Phases of procedures } & \multicolumn{6}{|c|}{ Architectural structure } \\
\hline & \multicolumn{3}{|c|}{ Masonry-concrete } & \multicolumn{3}{|c|}{ Steel-concrete } \\
\hline & BQ & $\mathrm{FF}(\mathrm{l})$ & Electricity (kwh) & BQ & $\mathrm{FF}(\mathrm{l})$ & Electricity (kwh) \\
\hline Field concrete $(t)$ & 91.0 & - & 4004 & 30.4 & - & 1338 \\
\hline Premixed concrete $(\mathrm{t})$ & 5.2 & - & 130 & 96.7 & - & 2418 \\
\hline Excavation work $\left(\mathrm{m}^{3}\right)$ & 66.7 & 200.1 & - & 100.0 & 300.0 & - \\
\hline Land leveling $\left(\mathrm{m}^{2}\right)$ & 16.7 & 3.3 & - & 10.0 & 2.0 & - \\
\hline Lifting $(\mathrm{t})$ & 135.9 & 38.1 & - & 141.9 & 39.7 & - \\
\hline Lighting $\left(\mathrm{m}^{2}\right)$ & 100 & - & 2600 & 100 & - & 2600 \\
\hline Total & & 241.5 & 6734 & & 341.7 & 6356 \\
\hline
\end{tabular}

Note: (1) BQ indicates the bill of quantities for building projects. (2) FF indicates fossil fuels. 
Table 12

Annual average energy use for per $100 \mathrm{~m}^{2}$ of operating buildings.

\begin{tabular}{lccc}
\hline & $\begin{array}{l}\text { Other operational } \\
\text { activities of buildings }\end{array}$ & Heating & Total \\
\hline Coal $^{\text {eq }}(\mathrm{kg})$ & 35 & 1240 & 1275 \\
Fuels $(\mathrm{l})$ & 7.05 & - & 7.05 \\
Natural gas $\left(\mathrm{m}^{3}\right)$ & 125.76 & - & 125.76 \\
Electricity (kwh) & 1651 & - & 1651 \\
\hline
\end{tabular}

Table 13

Average energy use per $100 \mathrm{~m}^{2}$ of demolished buildings.

\begin{tabular}{lccccc}
\hline Procedure of construction & \multicolumn{3}{l}{ Architectural structure } & \\
\cline { 2 - 3 } & \multicolumn{2}{l}{ Masonry-concrete } & & \multicolumn{2}{l}{ Steel-concrete } \\
\cline { 2 - 3 } \cline { 5 - 6 } & $\mathrm{BQ}$ & $\mathrm{FF}(\mathrm{l})$ & & $\mathrm{BQ}$ & $\mathrm{FF}(\mathrm{l})$ \\
\hline Fragmentation $\left(\mathrm{m}^{2}\right)$ & 100 & 78 & & 100 & 78 \\
Excavation work $\left(\mathrm{m}^{3}\right)$ & 66.7 & 200.1 & & 100 & 300 \\
Land leveling $\left(\mathrm{m}^{2}\right)$ & 16.7 & 3.3 & & 10 & 2.0 \\
Lifting $(\mathrm{t})$ & 135.9 & 38.1 & & 141.9 & 39.7 \\
Total & & 319.5 & & 419.7 \\
\hline
\end{tabular}

Note: (1) BQ indicates the bill of quantities for building projects. (2) FF indicates fossil fuels.

materials so as to save energy to a certain degree. Most of recycled bricks, gravel and sand may be used as building or roadbed materials, which means its percentage of energy saving becomes an equivalent to $100 \%$. Recycled steels need to be melted and forged before re-using, which means that about $40 \%$ of the additional energy is needed to reproduce it. Therefore, the amount of energy saving for different kinds of materials is quantified by energy-saving ratio (ESR) in this study (Table 15).

\subsubsection{Life cycle energy flows of residential building system}

According to the analysis above, we presented an energy flows chart for residential building system shown in Fig. 3.

\section{3. $\mathrm{CO}_{2}$ emissions of residential building system}

Based on the analyses of materials and energy flows of residential building system, the LCCE model discussed in Section 3.1 were used to calculate the $\mathrm{CO}_{2}$ emission of residential buildings for masonry-concrete and steel-concrete architectural structures, see Table 16

\section{Results and discussions}

\subsection{Characteristics of $\mathrm{CO}_{2}$ emissions for residential buildings}

\subsubsection{Temporal characteristics}

The amount of $\mathrm{CO}_{2}$ emissions in the life cycle of residential buildings with masonry-concrete and steel-concrete structures is $329.61 \mathrm{t}$ and $315.79 \mathrm{t}$ per $100 \mathrm{~m}^{2}$, respectively. During the life cycle of typical residential buildings, it was indicated that $85-90 \%$ of $\mathrm{CO}_{2}$ emissions were created in the phase of building operation, 7-11\% came from constructive materials preparation and 3\% came from construction. Compared to the three phases above, building demolition generated fewer $\mathrm{CO}_{2}$ emissions. Besides, the treatment and recycling of building wastes can reduce $\mathrm{CO}_{2}$ emissions to some extent, which should be attached importance to. Based on the analysis before, the key to realize a goal of low-carbon urban residential buildings is to reduce the energy consumption and land footprint in the building operation phase (Fig. 4).

\subsubsection{Characteristics of $\mathrm{CO}_{2}$ emissions sources}

Among the four sources of $\mathrm{CO}_{2}$ emissions, $78-85 \%$ of $\mathrm{CO}_{2}$ emissions resulted from energy consumption and $13-20 \%$ were caused by land footprint. The percentage for industrial process emissions was relatively low, which was $2-4 \%$. And fugitive emissions were very few which could be neglected in the analysis. Most researches have pointed out the importance of carbon abatement by energy saving, while neglecting the potentials by reducing land footprint of urban building systems (Fig. 5).

\subsection{Influencing factors of industrial process emissions and potentials of $\mathrm{CO}_{2}$ reduction}

In a building life cycle, industrial process emissions were mainly from cement and steel production. For the same building area of $100 \mathrm{~m}^{2}$, the residential buildings with steel-concrete architectural structure created $4.93 \mathrm{t}$ more $\mathrm{CO}_{2}$ emissions than those with masonry-concrete architectural structure. As shown in Fig. $6,83-85 \%$ of $\mathrm{CO}_{2}$ emissions were from cement production because of the larger use amount and a relative high emission

Table 14

Average energy use for wastes transportation.

\begin{tabular}{|c|c|c|c|c|c|}
\hline & $\mathrm{CW}(\mathrm{t})$ & $\mathrm{DW}(\mathrm{t})$ & $\operatorname{TW}(\mathrm{t})$ & Distance $(\mathrm{km})$ & $\mathrm{FF}\left(\mathrm{kg} \mathrm{coal}^{\mathrm{eq}}\right)$ (by road) \\
\hline Masonry-concrete & 4.15 & 63.47 & 67.62 & 20 & 123 \\
\hline Steel-concrete & 4.40 & 66.34 & 70.74 & 20 & 129 \\
\hline
\end{tabular}

Note: CW, DW have the same meaning as that in Table 5, TW indicates the total amount of wastes, which is the sum of CW and DW.

Table 15

Average energy saving by wastes recycling.

\begin{tabular}{|c|c|c|c|c|c|c|c|c|}
\hline \multirow[t]{3}{*}{ Building materials } & \multicolumn{8}{|c|}{ Architectural structure } \\
\hline & \multicolumn{4}{|c|}{ Masonry-concrete } & \multicolumn{4}{|c|}{ Steel-concrete } \\
\hline & $R A(t)$ & $\operatorname{ESR}(\%)$ & $\mathrm{FF}\left(\mathrm{kg} \mathrm{coal}^{\mathrm{eq}}\right)$ & Electricity (kwh) & $R A(t)$ & ESR (\%) & $\mathrm{FF}\left(\mathrm{kg} \mathrm{coal}^{\mathrm{eq}}\right)$ & Electricity (kwh) \\
\hline Cement & 1.45 & 20 & 35 & 40.6 & 2.39 & 20 & 57 & 66.9 \\
\hline Steel & 2.14 & 60 & 629 & 184.9 & 5.04 & 60 & 1482 & 435.5 \\
\hline Timber & 0.13 & 10 & 1 & 0.9 & 0.15 & 10 & 1 & 1.1 \\
\hline Brick & 18.19 & 100 & 509 & 218.3 & 3.98 & 100 & 111 & 47.8 \\
\hline Gravel & 21.47 & 100 & 21 & 1073.5 & 35.33 & 100 & 35 & 1766.5 \\
\hline Sand & 25.90 & 100 & 26 & 1295 & 24.27 & 100 & 24 & 1213.5 \\
\hline Total & & & 1221 & 2813.2 & & & 1710 & 3531.3 \\
\hline
\end{tabular}

Note: (1) RA indicates recycled amount of building wastes, ESR means energy-saving ratio for building materials. (2) FF indicates fossil fuels. 
A life cycle process of residential buildings with masonry-concrete architectural structure

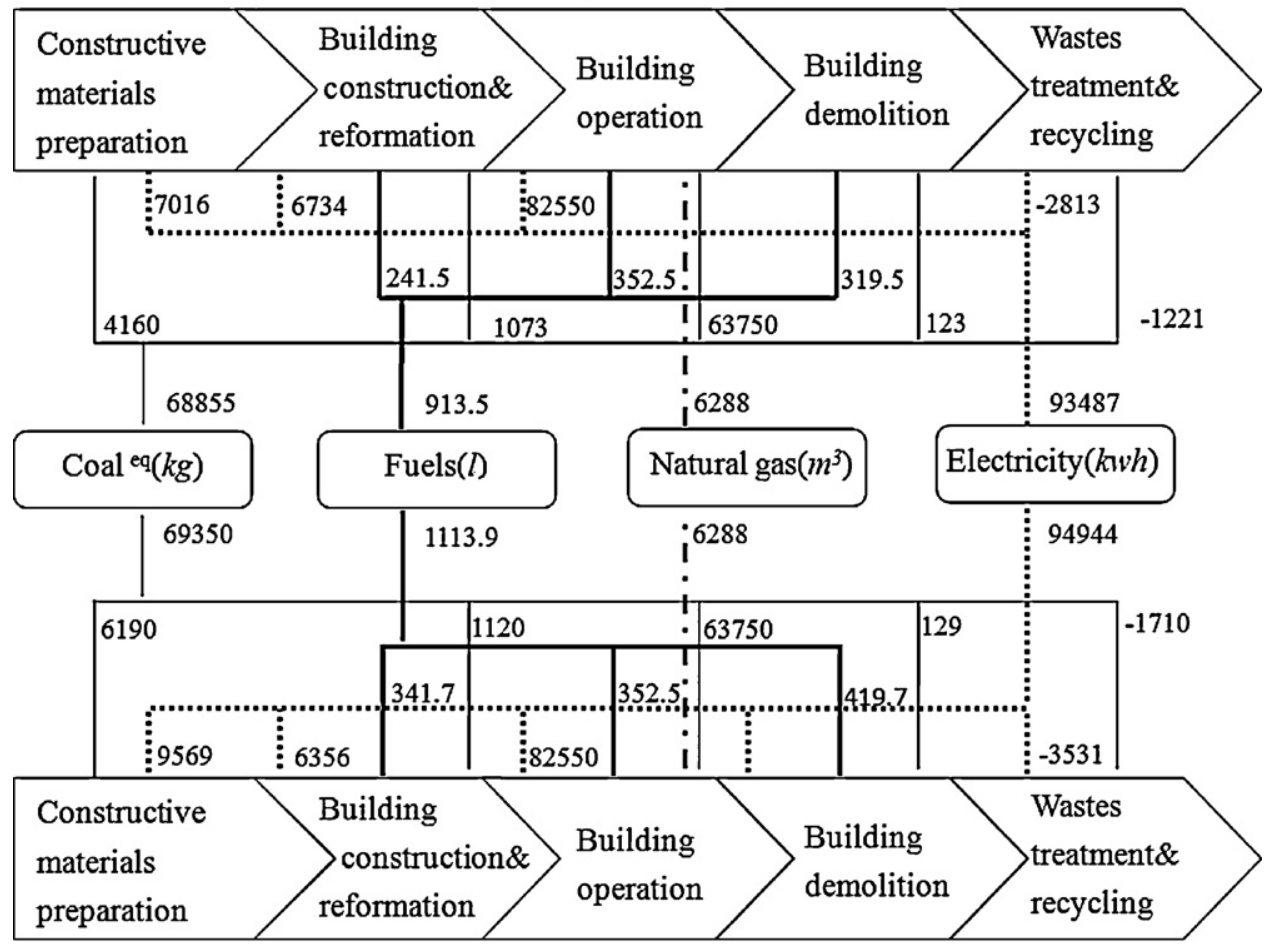

A life cycle process of residential buildings with steel-concrete architectural structure

Fig. 3. Energy flow chart of residential buildings per $100 \mathrm{~m}^{2}$ with different architectural structures.

factor. According to current technology of cement production, it is very hard to reduce emissions in this phase of production unless cutting down the use amount of cement and steel, or developing other new productive technologies which can substitute a new type of building materials with much less production emissions than the current type of cement products.

\subsection{Emission characteristics of energy consumption and its potentials of $\mathrm{CO}_{2}$ abatement}

The amount of $\mathrm{CO}_{2}$ coming from energy consumption was $257.25 \mathrm{t}$ and $262.9 \mathrm{t}$ per $100 \mathrm{~m}^{2}$ for residential buildings with masonry-concrete and steel-concrete architectural structure respectively. steel-concrete residential buildings consumed more energy in the phase of constructive materials preparation, building construction and building demolition, while during the phase of wastes treatment and recycling, it saved more energy than that of masonry-concrete buildings mainly because more steel could be recycled.

Most energy was consumed in the operation phase, the amount of $\mathrm{CO}_{2}$ emissions reaching $238.61 \mathrm{t}$ per $100 \mathrm{~m}^{2}$, which accounted for $90 \%$ of the total amount. And almost $60 \%$ of energy was used for heating. When a residential building satisfied the China's state standard for energy saving, the patterns of living energy consumption might determine the total use amount of energy. Therefore, changing the consumption pattern to a level of high efficiency and energy saving was the key to decrease $\mathrm{CO}_{2}$ emissions.

According to the analysis above, there are various kinds of practical ways to reduce $\mathrm{CO}_{2}$ emissions in different phases of a building life cycle. Firstly, it is possible to reduce $\mathrm{CO}_{2}$ emissions by changing the composition of energy consumption. From this aspect, it is shown that coal accounts for almost $60 \%$ of the total energy consumption, and the second is electricity, which is about $30 \%$ and only $10 \%$ is provided by natural gases or other energy. It is obvious that other clean primary energy (solar energy, wind and biomass etc.) are not efficiently used in the residential building system in China, but there is a great potential for better utilizing them. Besides, electricity also can be produced by cleaner primary energy such as solar or wind energy. Adjusting the use pattern of primary energy to produce electricity may help to decrease $\mathrm{CO}_{2}$ emissions. For example, in China currently, the percentage of clean

Table 16

$\mathrm{CO}_{2}$ emissions of a residential building system (unit: $\mathrm{t} / 100 \mathrm{~m}^{2}$ ).

\begin{tabular}{|c|c|c|c|c|c|c|c|c|}
\hline \multirow[t]{3}{*}{ Phases of life cycle } & \multicolumn{8}{|c|}{ Emission sources } \\
\hline & \multicolumn{2}{|l|}{ IE } & \multicolumn{2}{|l|}{$\mathrm{EE}$} & \multicolumn{2}{|l|}{$\mathrm{FE}$} & \multicolumn{2}{|l|}{$\mathrm{LE}$} \\
\hline & MC & SC & MC & SC & MC & SC & MC & SC \\
\hline Building materials preparation & 6.68 & 11.62 & 15.83 & 22.86 & - & - & ND & ND \\
\hline Building construction \& reformation & - & - & 8.68 & 8.77 & - & - & ND & ND \\
\hline Building operation & - & - & 236.81 & 236.81 & - & - & 61.51 & 36.83 \\
\hline Building demolishing & - & - & 1.18 & 1.48 & - & - & ND & ND \\
\hline Waste treatment and recycling & - & - & -5.25 & -7.02 & 0.83 & 0.95 & 3.34 & 3.49 \\
\hline Total & 6.68 & 11.62 & 257.25 & 262.9 & 0.83 & 0.95 & 64.85 & 30.32 \\
\hline
\end{tabular}

Note: MC indicates masonry-concrete, SC means steel-concrete. ND means that the original data were not available in our research. 


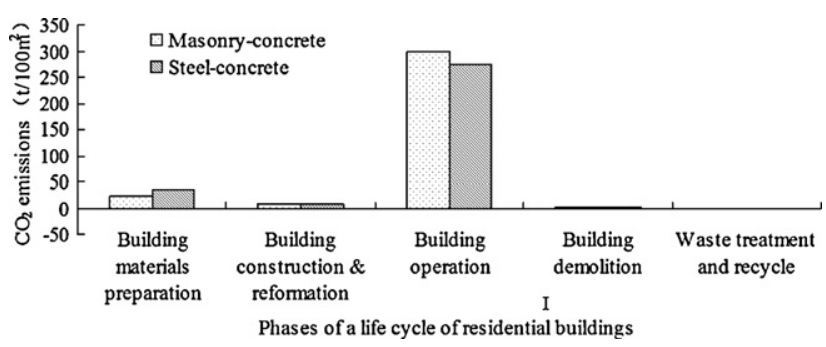

Fig. 4. Temporal characteristics of $\mathrm{CO}_{2}$ emissions for residential buildings.

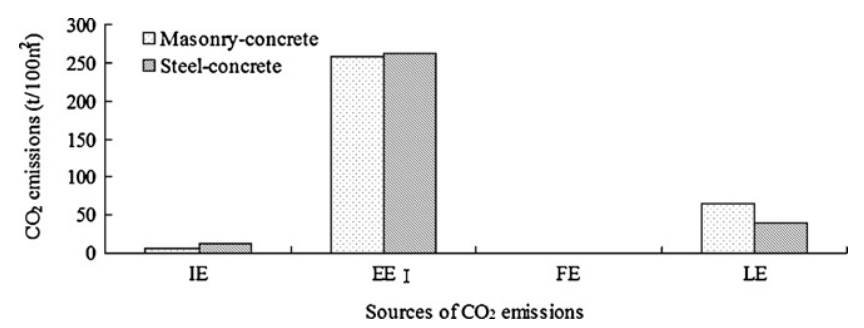

Fig. 5. Characteristics of $\mathrm{CO}_{2}$ emissions sources for two categories of architectural structures.

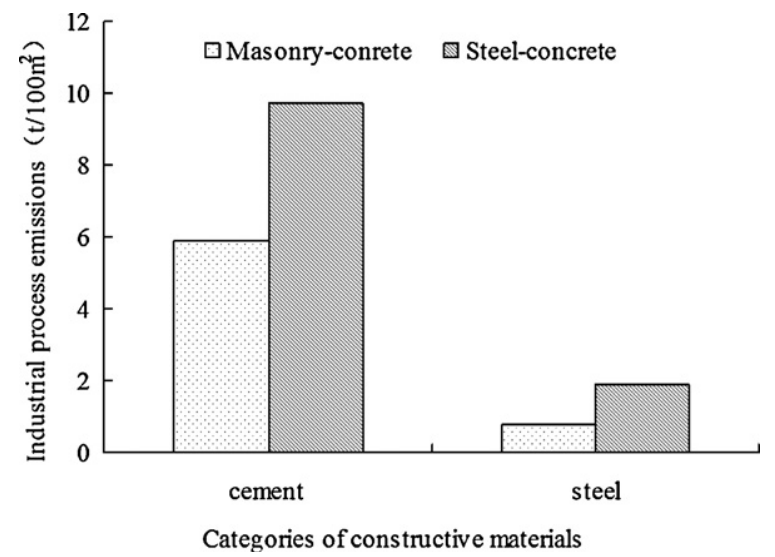

Fig. 6. Industrial process emissions for residential buildings.

primary energy in the total energy use is only $3 \%$, while the average percentage in the world is $29 \%$ in 2008 (BP, 2009). If the local government invested more money on hydro-electricity and nuclear power or other alternative clean energy, it would be possible to improve the percentage of clean power up to $20 \%$, which means $20.2 \mathrm{t}$ of $\mathrm{CO}_{2}$ emission reduction per $100 \mathrm{~m}^{2}$ of residential buildings. Secondly, even if the level of electricity production remained stable, if the efficiency of electricity production could be improved to $300 \mathrm{~g} \mathrm{coal}^{\mathrm{eq}} / \mathrm{kwh}$, which might be achieved by contemporary technology, the potential of $\mathrm{CO}_{2}$ reduction would reach $10.8 \mathrm{t}$ per $100 \mathrm{~m}^{2}$ for residential buildings. Last but not least, from the aspect of energy consumption, the building design standard to save energy for $65 \%$ in residential buildings would be carried out in 2010 in China, which means energy consumption for heating may decrease up to $8.24 \mathrm{~kg}_{\text {coal }}{ }^{\mathrm{eq}} /$ $\left(\mathrm{m}^{2} \mathrm{a}\right)$. For a $100 \mathrm{~m}^{2}$ of residential building, the potential of $\mathrm{CO}_{2}$ reduction can reach $26.1 \mathrm{t}$ per $100 \mathrm{~m}^{2}$ during its life cycle.

\subsection{Potential of $\mathrm{CO}_{2}$ reduction for constructive materials}

\subsubsection{Characteristics of $\mathrm{CO}_{2}$ emissions of constructive materials}

As the second largest contributor to $\mathrm{CO}_{2}$ emissions, constructive materials are quite different from each other. In the phase of constructive materials preparation, for $100 \mathrm{~m}^{2}$ of building area, buildings of steel-concrete architectural structure consume energy and bring about $22.9 \mathrm{t}$ of $\mathrm{CO}_{2}$ emissions per $100 \mathrm{~m}^{2}$, while the amount for masonry-concrete architectural structure is about $12.8 \mathrm{t}$ per $100 \mathrm{~m}^{2}$ because more cement and steel are used in buildings of steel-concrete architectural structure. The contribution percentages of constructive materials to $\mathrm{CO}_{2}$ emissions in masonry-concrete architectural structure buildings are $38 \%$ for cement, $21 \%$ for steel, $18 \%$ for brick, $12 \%$ for sand, $10 \%$ for gravel and $1 \%$ for timber, and the figures for steel-concrete architectural structure buildings are $43 \%, 34 \%, 3 \%, 8 \%, 11 \%$ and $1 \%$ respectively. To reduce emissions in this stage, we need focus on energy saving of cement and steel production (Fig. 7).

5.4.2. Building material and waste recycling in residential buildings

It is possible to save energy and reduce $\mathrm{CO}_{2}$ emissions by the recycling of building wastes. As shown in Fig. 8, during the phase of wastes treatment and recycling, the reduction amount of $\mathrm{CO}_{2}$ emissions is $5.2 \mathrm{t}$ per $100 \mathrm{~m}^{2}$ for buildings of masonry-concrete architectural structure and $7.0 \mathrm{t}$ per $100 \mathrm{~m}^{2}$ for buildings of steelconcrete architectural structure, which mainly result from the recycling of cement and steel.

Energy saving and emission reduction vary a lot because of different recycling rates and re-use pattern. In this study, we compared the $\mathrm{EF}$ (emissions factors, including industrial process emissions and energy consumption emissions: the ratio of $\mathrm{CO}_{2}$ emission to use amount of each type of constructive materials), WRR (wastes recycling rates: the ratio of recycled wastes to total wastes of each constructive material) and ERP (emission reduction percentages: the ratio of $\mathrm{CO}_{2}$ reduction amount to the total emissions of each type of constructive materials) among the six
Masonry-concrete

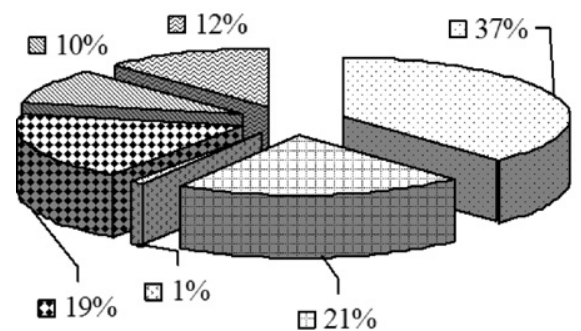

Steel-concrete

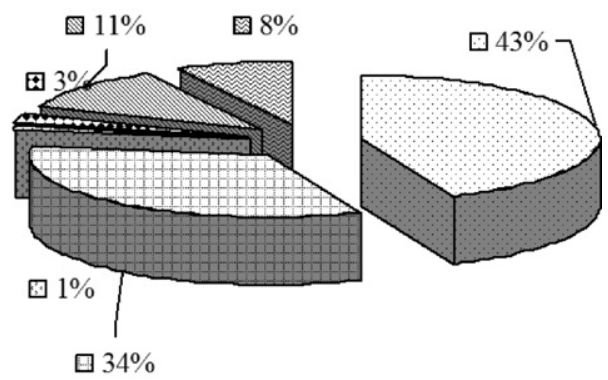

Fig. 7. Composition of $\mathrm{CO}_{2}$ emissions in the phase of constructive materials preparation. 


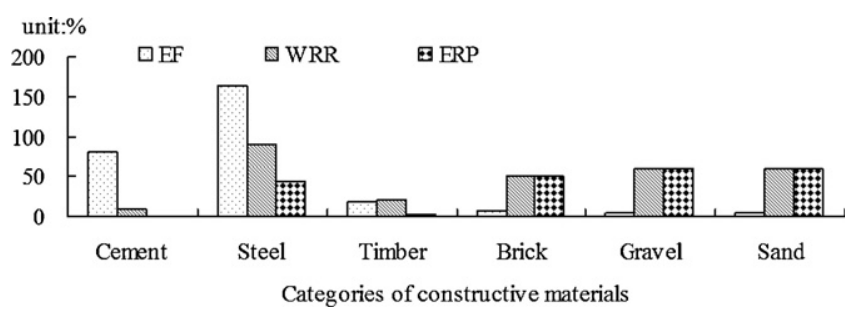

Fig. 8. Characteristics of $\mathrm{CO}_{2}$ emissions by recycling for different constructive materials.

kinds of constructive materials. From the aspect of EF (Fig. 8), $1 \mathrm{t}$ steel results in the largest amount of $\mathrm{CO}_{2}$ emissions, reaching as much as $1.64 \mathrm{t}$, which is followed by cement of $0.80 \mathrm{t}$, timber of $0.17 \mathrm{t}$, brick of $0.08 \mathrm{t}$, gravel of $0.04 \mathrm{t}$ and sand of $0.04 \mathrm{t}$. As for the recycling rates, $90 \%$ of the steel wastes can be recycled, and the figure for brick, gravel and sand is above 50\%. However, the recycling rates of cement and timber are relatively low. From the aspect of ERP, steel, brick, gravel and sand have relative high levels of emission reduction percentage which are about $50 \%$, while the figures of cement and timber are low. Based on the three factors discussed above, there are various measures for us to reduce $\mathrm{CO}_{2}$ emissions from constructive materials. Firstly, we need to decrease the emission factors by improving energy efficiency. For example, heat recovering technology is applied in many industrial sectors in China, including cement and steel, which could help improve energy efficiency; Secondly, effective management may help to improve the recycling rates of building wastes. Besides, it also could be very helpful to save more energy by employing the new technologies of re-use of building wastes.

\subsection{Potentials of land footprint emissions reduction}

\subsubsection{Characteristics of land footprint emissions}

Compared to the buildings with steel-concrete architectural structure, the buildings with masonry-concrete architectural structure could bring about more $\mathrm{CO}_{2}$ emissions of $24 \mathrm{t}$ per $100 \mathrm{~m}^{2}$. As discussed above, land footprint emissions were a kind of emissions with a change of land use, which mainly came from building wastes and building itself. As shown in Fig. 9, the former constituted about $5-9 \%$ of the total emissions, while the latter accounted for $91-95 \%$. The results of analysis indicated that the emissions resulted from land footprint by a building itself were one of the main sources, which had not been paid enough emphasis in the previous studies.

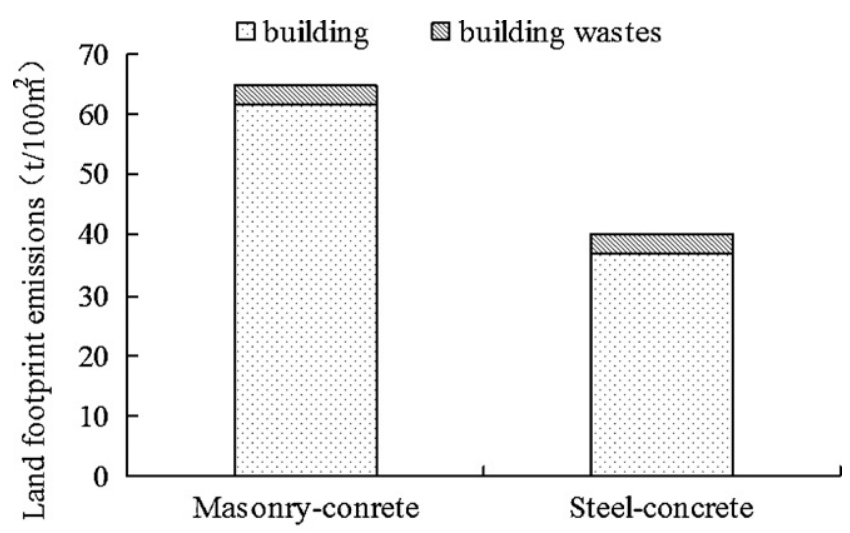

Types of architectural structrues

Fig. 9. Land footprint emissions for different categories of architectural structures.

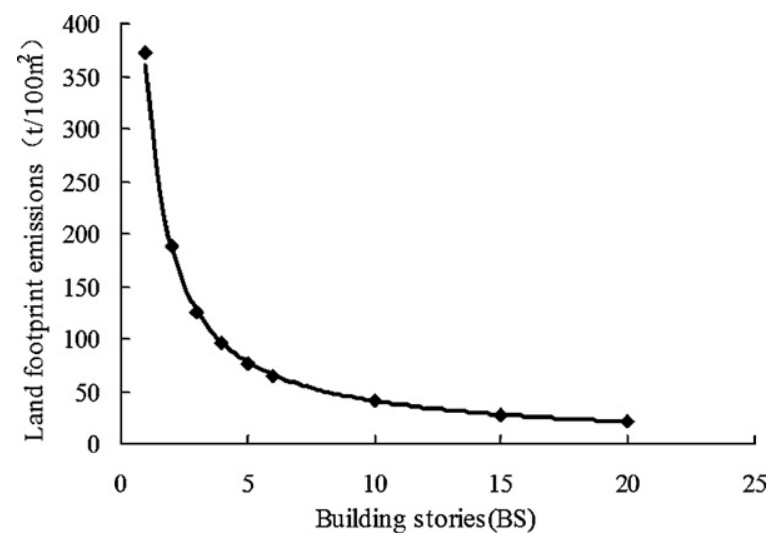

Fig. 10. A quantitative relationship between land footprint emissions and building stories (BS).

\subsubsection{Influences of building stories on land footprint $\mathrm{CO}_{2}$ emissions}

Generally speaking, for the sake of saving of land resources, it is a tendency to build more high-rise buildings. In China nowadays, a lot of flat houses and low-storey buildings have been replaced by the modern high-rise buildings in Beijing and other rapidly developing cities. According to the analysis above, we found out that land footprint emissions accounted for about $13-20 \%$ of the total emissions. In this study, buildings of steel-concrete architectural structure with 10 stories can reduce $24 \mathrm{t}$ per $100 \mathrm{~m}^{2}$ of $\mathrm{CO}_{2}$ emissions in comparison to buildings of masonry-concrete architectural structure with 6 stories. How the stories of buildings influence the $\mathrm{CO}_{2}$ emissions? We made an analysis of correlation between land footprint emissions and building stories, showing that there is a correlation coefficient of 0.99 for power function $(P<0.01)$. As shown in Fig. 10 , the land footprint emissions of flat houses are 17 times of that of buildings with 20 stories, 9.2 times of that of buildings with 10 stories and 5.7 times of that of buildings with 6 stories. Furthermore, for a $100 \mathrm{~m}^{2}$ area of flat house, the land footprint emissions can reach as much as 370 t of $\mathrm{CO}_{2}$ emissions, which accounted for about $59 \%$ of the total emission amount in its life cycle, and was more than the sum coming from all other emission sources. It was clearly explained that the proper level of building stories is significant to reduce $\mathrm{CO}_{2}$ emissions in the life cycle of residential buildings, but it is not meant that the higher for building stories, the better for a reduction of $\mathrm{CO}_{2}$ emission.

\subsubsection{Impacts of floor area ratios (FAR) of buildings on their total $\mathrm{CO}_{2}$} emissions of a life cycle (TCE)

Floor area ratio (FAR) is an important indicator in urban architectural planning and management, which directly reflects the intensity of land use. Just as discussed above, we can raise FAR value by increasing building stories or changing designs of architectural structures which greatly helps reduce $\mathrm{CO}_{2}$ emissions of residential buildings. In our analysis, there is a correlation coefficient of 0.97 for power function between FAR and TCE of buildings $(P<0.01)$. If we raise FAR value from 1.0 to 1.5 , it can decrease $245.5 \mathrm{t}$ of TCE per $100 \mathrm{~m}^{2}$ in a building life cycle (Fig. 11). Nevertheless, it also should be pointed out that higher value of FAR indicates higher intensity of land use and greater ecological pressure on urban infrastructures and surrounding ecosystem processes, so a proper or moderate value of FAR is much better for building a sustainable urban building system. It is possible that a city may have higher FAR and lower carbon emission based on a limit of local ecosystem services, and this issue will be explored further in our future research. 


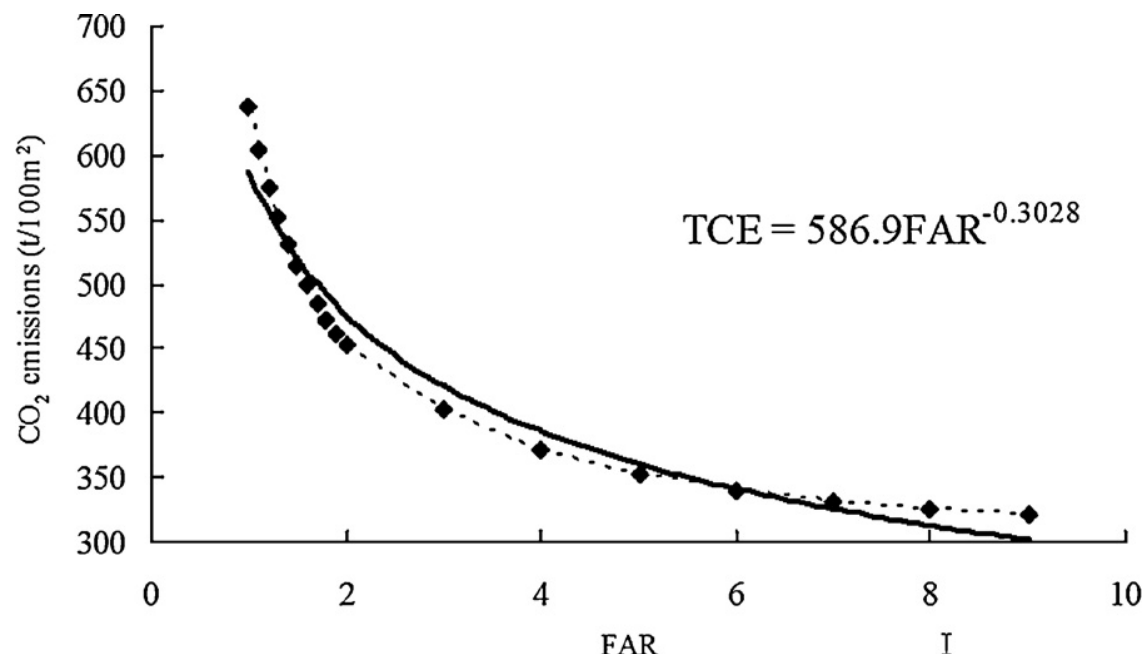

Fig. 11. A quantitative relationship between total $\mathrm{CO}_{2}$ emissions of a building life cycle (TCE) and its floor area ratio (FAR).

\section{Conclusions}

Urban building system is one of the biggest sources of $\mathrm{CO}_{2}$ emissions. Our research introduces a newly developed carbon emissions model (LCCE model) to analyze $\mathrm{CO}_{2}$ emissions of urban building system based on the principle of LCA. A case study from some typical residential buildings of different architectural structures in China was also employed to illustrate how the model help us understand and analyze $\mathrm{CO}_{2}$ emissions in the different phases of a building life cycle and the differences between buildings with two different architectural structures.

It was shown that the $\mathrm{CO}_{2}$ emissions during the life cycle of residential buildings mainly came from energy consumption and land footprint. Buildings of masonry-concrete architectural structure created more $\mathrm{CO}_{2}$ emissions than the steel-concrete structure with the same area. The keys to reduce $\mathrm{CO}_{2}$ emissions of urban building system are to promote the recycling of constructive materials, transformation of patterns of citizens' consumption and improvement of building floor area ratio in a proper extent.

Our research presents a useful analysis for helping understand the characteristics of carbon emissions of urban buildings, and how the architectural factors affect the carbon emissions of urban buildings as well as the possible potentials for the abatement of carbon emissions for urban buildings. The results from this study provide some references for improving and optimizing the planning and designs of urban building system.

\section{Acknowledgements}

This research was supported by National Foundation of Natural Sciences of China (70873121) and the State Key Laboratory of Urban \& Regional Ecology (SKLURE2008-1-01). This work was also supported by Knowledge Innovation Project of Chinese Academy of Sciences (KZCX2-YW-324) and the Key Supporting Project of Ministry of Science and Technology of China (2007BAC28B04).

\section{References}

Arena, A.P., Rosa, C., 2003. Life cycle assessment of energy and environmental implications of the implementation of conservation technologies in school buildings in Mendoza-Argentina. Building and Environment 38, 359-368.

British Petroleum (BP), 2009. BP Statistical Review of World Energy June 2009. , London.

Buchanan, A.H., Levine, S.B., 1999. Wood-based building materials and atmospheric carbon emissions. Environmental Science \& Policy 2, 427-437.
Chakraborty, A., Bhattacharya, D.K., Li, B.L., 2006. Spatiotemporal dynamics of methane emission from rice fields at global scale. Ecological Complexity 3, 231-240.

Chen, C., Hu, D., Wen, Q.X., Zhang, D.K., 2007. Resource depletion and environmental discharge of cement production in China. Journal of Anhui Agricultural Sciences 35, 8986-8989 (in Chinese)

Chen, Z.X., Su, X.M., 1998. Study on ecological benefits of urban landscape architecture in Beijing(III). Chinese Landscape Architecture 14, 53-56 (in Chinese).

Churkina, G., Tenhunen, J., Thornton, P., Falge, E.M., Elbers, J.A., Erhard, M., Grünwald, T., Kowalski, A.S., Rannik, Üllar, Sprinz, D., 2003. Analyzing the ecosystem carbon dynamics of four European coniferous forests using a biogeochemistry model. Ecosystems 6, 168-184.

Dimoudi, A., Tompa, C., 2008. Energy and environmental indicators related to construction of office buildings. Resources, Conservation and Recycling 53, 86-95.

Ding, H.T., Liu, H.Z., Wang, L.L., 2009. Preliminary analysis of the energy consumption statistics in civic buildings. Heating Ventilatings \& Air Conditioning 39, 1-3 (in Chinese).

Dodoo, A., Gustavsson, L., Sathre, R., 2009. Carbon implications of end-of-life management of building materials. Resources, Conservation and Recycling 53, 276-286.

Gielen, D., Moriguchi, Y., 2002. $\mathrm{CO}_{2}$ in the iron and steel industry: an analysis of Japanese emission reduction potentials. Energy Policy 30, 849-863.

Gustavsson, L., Sathre, R., 2006. Variability in energy and carbon dioxide balances of wood and concrete building materials. Building and Environment 41, 940-951.

Hu, D., You, F., Zhao, Y.H., Yuan, Y., Cao, A.X., Liu, T.X., Wang, Z., Zhang, J.L., 2010. Input, stocks and output flows of urban residential building system in Beijing city, China from 1949 to 2008. Resources, Conservation \& Recycling 54, 11771188.

Huang, S.L., Hsu, W.L., 2003. Materials flow analysis and energy evaluation of Taipei's urban construction. Landscape and Urban Planning 63, 61-74.

IPCC, 2006. IPCC Guidelines for National Greenhouse Gas Inventories, Prepared by the National Greenhouse Gas Inventories Programme. IGES, Japan.

IPCC, 2007. Fourth Assessment Report: Climate Change.

Josa, A., Aguado, A., Heino, A., Byars, E., Cardim, A., 2004. Comparative analysis of available life cycle inventories of cement in the EU. Cement and Concrete Research 34, 1313-1320.

Kneifel, J., 2010. Life-cycle carbon and cost analysis of energy efficiency measures in new commercial buildings. Energy and Buildings 42, 333-340.

Koroneos, C., Dompros, A., 2007. Environmental assessment of brick production in Greece. Building and Environment 42, 2114-2123.

Li, G., 2009. Study on reclamation of urban construction wastes. M.S. Thesis. Chang'an University, Xi'an (in Chinese).

Li, J., Colombier, M., 2009. Managing carbon emissions in China through building energy efficiency. Journal of Environmental Management 90, $2436-2447$.

Ma, Y., 2004. Concise handbook of Construction Budget. Tianjin University Press, Tianjin (in Chinese).

National Bureau of Statistics (NBS), 2009a. China Energy Statistical Yearbook. China Statistics Press, Beijing (in Chinese).

National Bureau of Statistics (NBS), 2009b. China Statistical Yearbook. China Statistics Press, Beijing (in Chinese)

Nebel, B., Zimmer, B., Wegener, G., 2006. Life cycle assessment of wood floor coverings-a representative study for the German flooring industry. The International Journal of Life Cycle Assessment 11, 172-182.

Pataki, D.E., Emmi, P.C., Forster, C.B., Mills, J.I., Pardyjak, E.R., Peterson, T.R. Thompson, J.D., Dudley-Murphy, E., 2009. An integrated approach to improving fossil fuel emissions scenarios with urban ecosystem studies. Ecological Complexity $6,1-14$ 
Peng, W.Z., 2002. Study on building energy consumption based on LCA. M.S. Thesis. Chaoyang University of Technology, Taichung (in Chinese).

Potere, D., Schneider, A., 2007. A critical look at representations of urban areas in global maps. GeoJournal 69, 55-80.

Prato, T., 2008. Conceptual framework for assessment and management of ecosystem impacts of climate change. Ecological Complexity 5, 329-338.

Schuurmans, A., Rouwette, R., Vonk, N., Broers, J., Rijnsburger, H., Pietersen, H., 2005. LCA of finer sand in concrete. The International Journal of Life Cycle Assessment 10, 131-135.

Seppälä, J., Koskela, S., Melanen, M., Palperi, M., 2002. The Finnish metals industry and the environment. Resources, Conservation and Recycling 35, 61-76.

State Forestry Bereau (SFB), 2005. Forest Industry Standard in People's Republic of China, Energy Consumption of Forest Timber Production LY/T1444-2005. Chinese Standard Press, Beijing (in Chinese).
Torssell, B., Eckersten, H., Kornher, A., Boström, U., 2007. Modelling carbon dynamics in mixed grass-red clover swards. Agricultural Systems 94, 273-280.

Tukker, A., 2000. Life cycle assessment as a tool in environmental impact assessment. Environmental Impact Assessment Review 20, 435-456.

Ulgiati, S., Brown, M.T., 1998. Monitoring patterns of sustainability in natural and man-made ecosystems. Ecological Modelling 108, 23-36.

Warren-Rhodes, K., Koenig, A., 2001. Escalating trends in the urban metabolism of Hong Kong: 1971-1997. AMBIO 30, 429-438.

West, T.O., Marland, G., 2002. A synthesis of carbon sequestration, carbon emissions, and net carbon flux in agriculture: comparing tillage practices in the United States. Agriculture, Ecosystems \& Environment 91, 217-232.

Wolman, A., 1965. The metabolism of cities. Scientific American 213, 179-188.

Zhang, Z., Wu, X., Yang, X.M., Zhu, Y.M., 2006. BEPAS-a life cycle building environmental performance assessment model. Building and Environment 41, 669-675. 